\title{
Visible Light Communication Kits for Education
}

\author{
Syifaul Fuada (Corresponding Author) \\ University Center of Excellence on Microelectronics, Institut Teknologi Bandung \\ Email: Syifaulfuada@pme.itb.ac.id
}

Trio Adiono

University Center of Excellence on Microelectronics, Institut Teknologi Bandung

Received: February 2, 2018

doi:10.5296/jet.v5i2.12578
Accepted: April 5, 2018

Published: May 26, 2018

URL: http://dx.doi.org/10.5296/jet.v5i2.12578

\begin{abstract}
The development of educational kit must be compiled on how to prepare undergraduate students in the engineering field in following the new trends globally and becoming an alternative to the technical education system based on practical approach. The primary motivation for this research is to design and implement the visible light communications (VLC) educational toolkit, especially in the analog front-end part. It consisted of six kits (transimpedance amplifier, pre-amplifier, DC-offset remover, analog filter, and AGC) in which each kit has one practicum task. There are six tasks and one task for the project by integrating these kits. The undergraduate students can use this educational kit to investigate the physical layer in a VLC system. It provides a low-complexity educational kit, so this is becoming an alternative as supplement course offered in this field. Then, it has a simple design and user-friendly.
\end{abstract}

Keywords: Educational kits, Li-Fi, Visible light communication

\section{Introduction}

The research on VLC is becoming a prevalent topic in global, and many R\&D activities have been carried-out towards developing the VLC systems for indoor/outdoor applications, targeting for high- or low-rate data transmission purpose. M. Figueiredo et al. (2017: 28-37) reported that VLC as the one of the new trend in the field of telecommunications over last five years from 2010 to 2015, viewed from Google Scholar search engine and IEEE Xplore online library. In regards to 'research trends of VLC.' We re-investigate to update the data where its report is shown in Figure 1. The data have obtained from two popular databases above. We can observe it in the charts that the number of publications tending to increase.

Figure 2 depicts a VLC system consists of the transmitter, visible light link (modulated light) and the receiver. The emitter of VLC usually uses the light source (e.g., LEDs, LCD screen, except a fluorescent and incandescent) as a modulation device on the optical carrier at the visible light spectrum. While the VLC receiver is composed of photosensors (e.g., photodiode, 


\section{Macrothink

LDR, phototransistor, etc.) or image sensor. The next stage is amplifiers, signal recovery circuit, filters, and also auto-gain circuit. The VLC system was designed to employ direct detection based on LED intensity (C.G. Lee et al., 2011: 328-338).

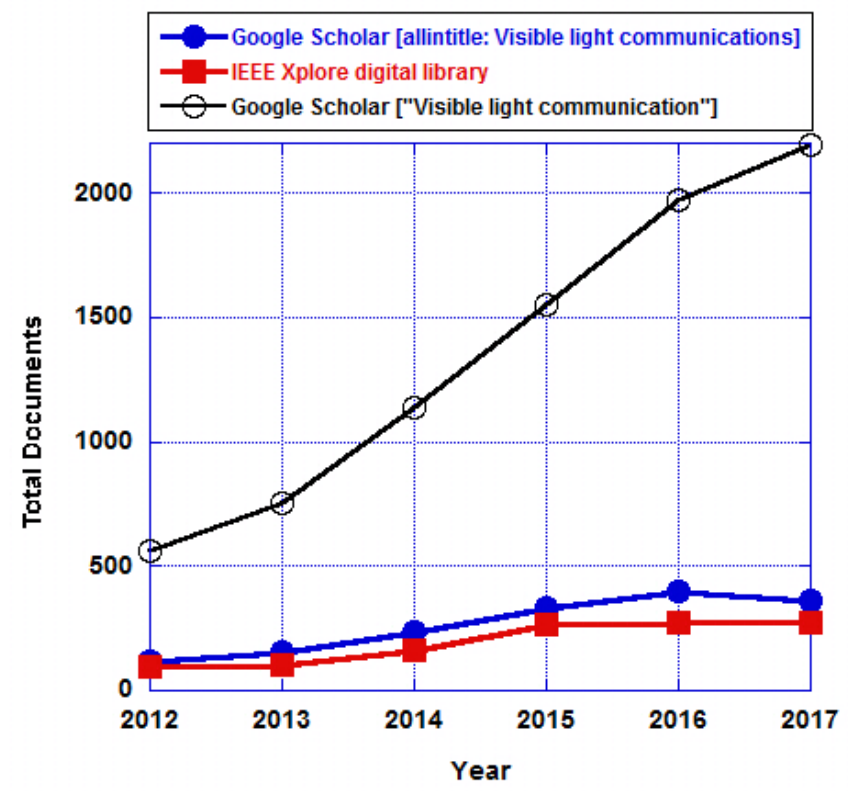

Figure 1. The illustration of research trend over the last five years by visualizing the number of search results for the search term [allintitle: Visible light communications] and ["Visible light communication"]. It was conducted using the Google scholar engine, then with search term [visible light communications \& visible light communication] conducted using the IEEE Xplore digital library, counted on Feb. 1, 2018, 05.00 PM

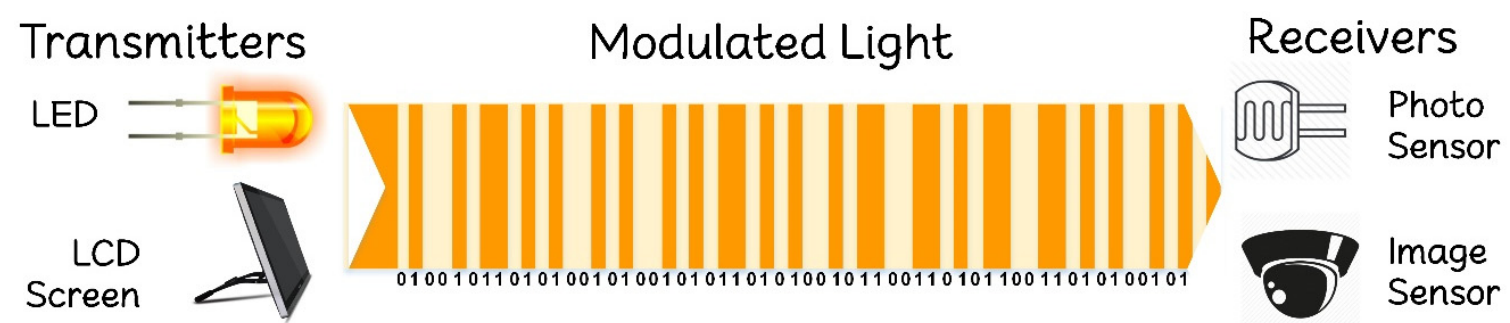

Figure 2. The structure of VLC system consisting Analog transceiver, an optical link, and transceiver device. The illustration was edited from C. Windlin (2017)

In respect of VLC development, there are several technology companies of VLC developers (new-startup company) as global market key players includes: PureLiFi Ltd. (UK), Koninklijke Philips N.V. (Netherland), General Electric Co. (U.S.), Panasonic Corp. (Japan), LVX system (Canada), Oledcomm (France), IBSENtelecom (Norway), etc. While the Disney research (Switzerland) focuses on the VLC implementation for toys. Given the popularity of this research scope area, the VLC systems need to be adopted by higher educations in their 
curriculum development to keep up continuously with the global research trend. Some have been performed-out concerning the adoption of VLC technology into the related courses that includes three levels of learning standards: elementary levels such as presented by C. Windlin (2017), L.B. Oliveira et al. (2017: 105-111), C. Windlin \& J. Laaksolahti (2017) and intermediate levels. Even to the advanced level that proposed by particular research groups such as reported by V. Vasinek et al. (2009) and A.M. Johnson et al. (2009).

However, following with our observations in the significant scientific database, there are still many colleges \& universities that either rarely to provide a practical approach in exploring the analog front-end circuitry for the VLC application. The related research found that proposed by A.A. Akram and J. Hill (2011: 4-9) and Q. Wang et al. (2015) but they focus on fiber optic communication or FSO, not for VLC purpose. Later, Q. Wang et al. (2015) introduces VLC kits for education purpose but focus on communication protocol (digital section), not in analog section. The analog part in VLC system has a vital role in processing the analog signal (S. Fuada, 2017).

According to the brief description of research backgrounds, so the primary motive for this work was the need for a low-complexity laboratory alternative for lecturing the undergraduate student in VLC system focusing on the analog part to additional courses covered in this topic. This VLC educational toolkit provides undergraduate students with a new way to study the physical layer of simple VLC systems. As stated before, this proposed kits can be used as the supplement courses offered in this field. Such as those associated with Op-Amps (e.g., sensors and transducers course, analog instrumentation, etc.), correlated with wireless communication (e.g., signal and processing course, emerging communication system, optical communication, etc.).

\section{Methodology}

In this section, we describe the design of educational kits for low-cost of VLC system for low-speed application, the number of the designed kits, and how to use these kits in practical-course. Firstly, we present the design of the kit. Since this course focuses on the low-speed VLC application, so there is no specific consideration in choosing the materials, as reported by L.B. Oliveira et al. (2017: 105-111).

"In a teaching laboratory environment, it is difficult to build circuits for high operating frequencies because this would require the design and manufacture of high-quality printed circuit boards with low parasitic capacitances. The only option is to select circuits and systems where the signal frequency is low so that high parasitic capacitances have a negligible impact on performance”.

Therefore, to fit with the low-complexity target, we develop the educational kit separately. Thus it can be practiced by plug-and-play as needed (portable kits) and also it can be evaluated per-block easily (user-friendly). The concept of educational kit for VLC depicted in Figure 3, that is analog front-end (AFE) in which each kit has three input channels for the supply voltage, i.e., $+5 \mathrm{VDC}$, ground (GND), and $-5 \mathrm{VDC}_{\mathrm{DC}}$. Whereas the ports on input and output, there are five channels, namely: $+5 \mathrm{~V}_{\mathrm{DC}}$, GND, $-5 \mathrm{~V}_{\mathrm{DC}}$, data and GND. 


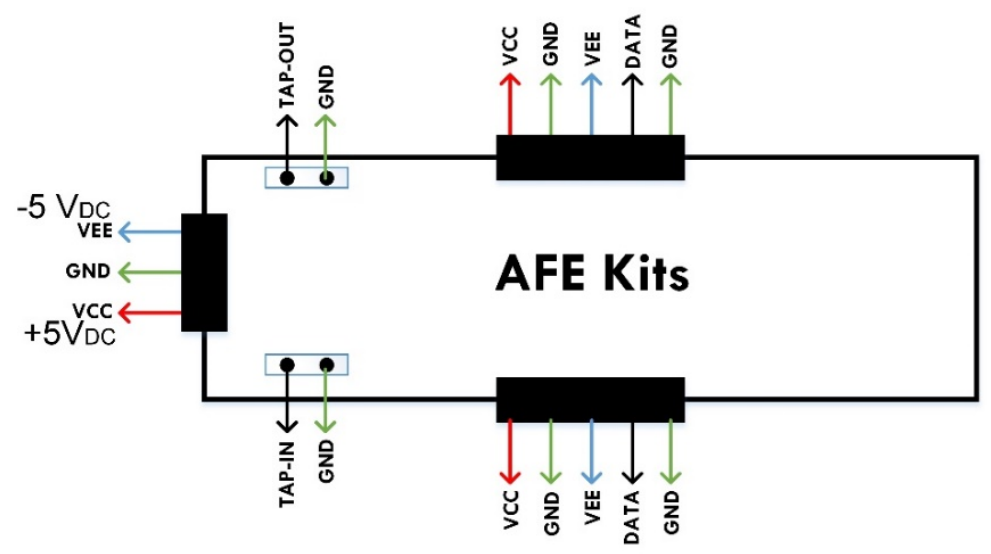

Figure 3. The design concept of low-complexity educational kits for low-speed VLC system

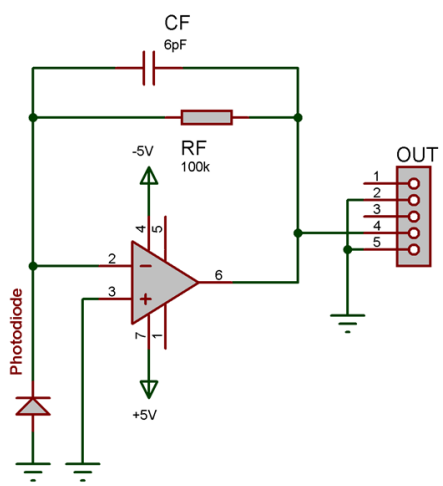

(a)

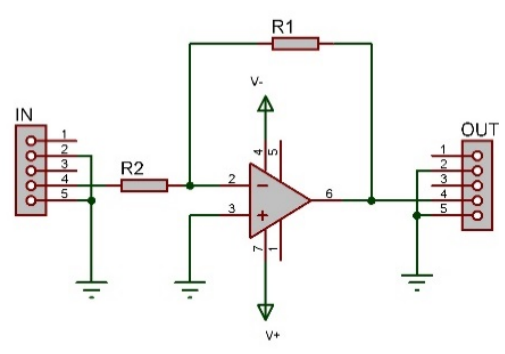

(d)

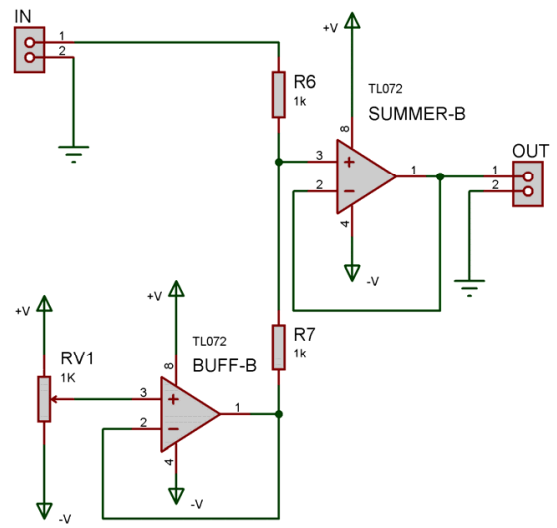

(b)

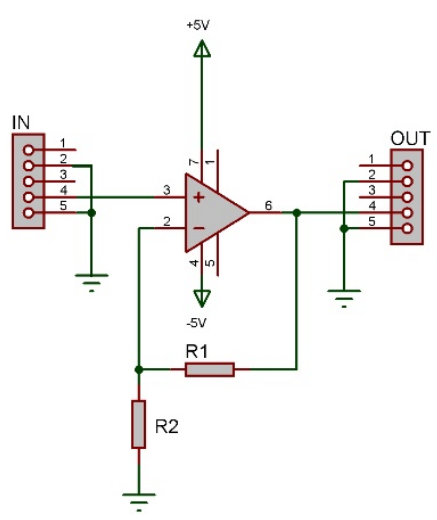

(c)

Figure 4. The design concept of low-complexity educational kits for VLC 


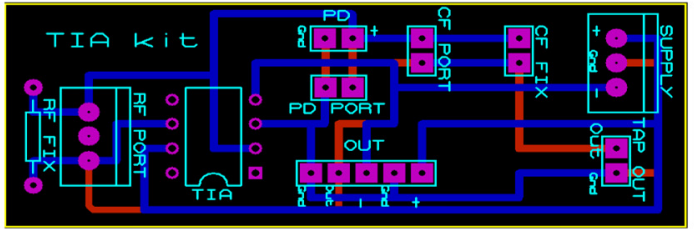

(a)

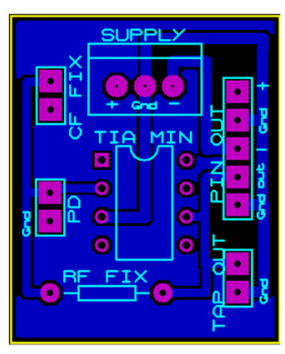

(b)

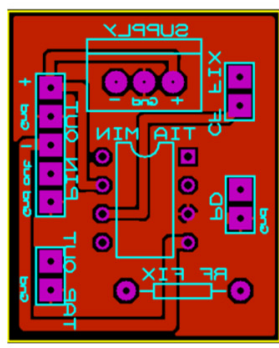

(c)

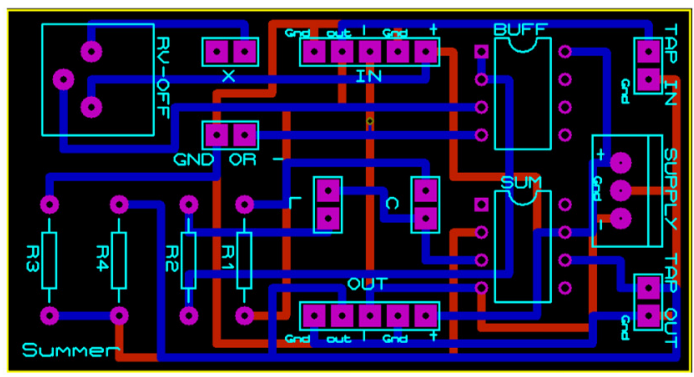

(d)

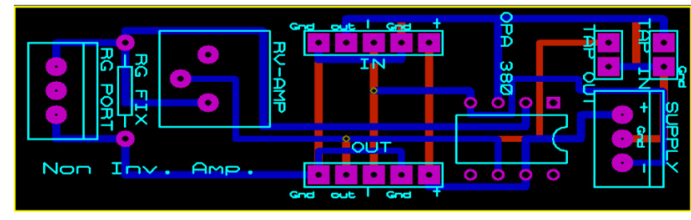

(e)

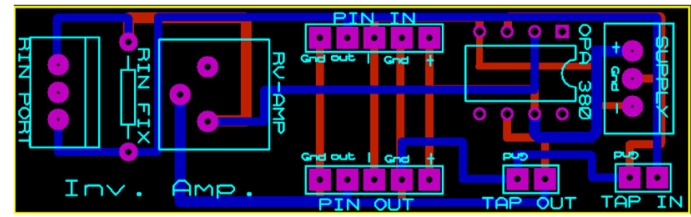

(g)

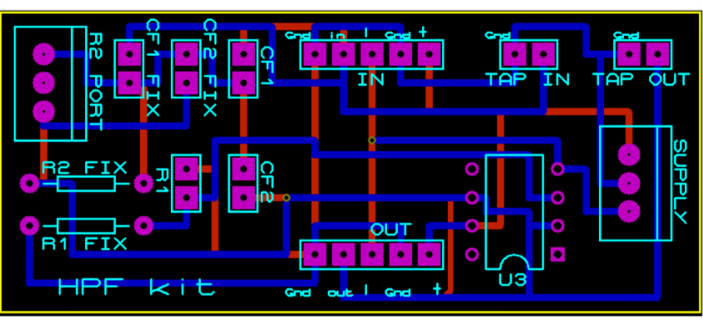

(i)

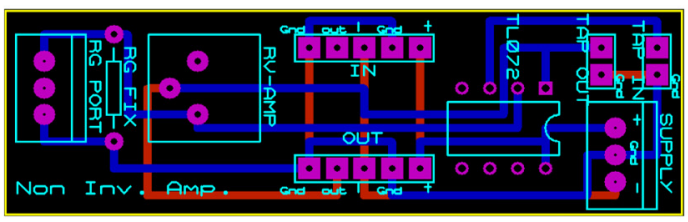

(f)

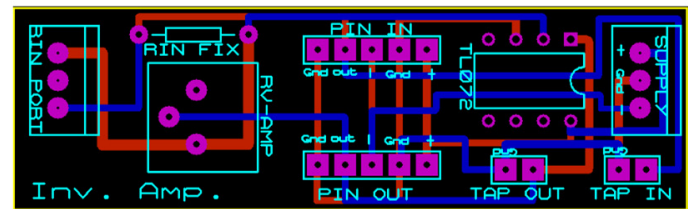

(h)

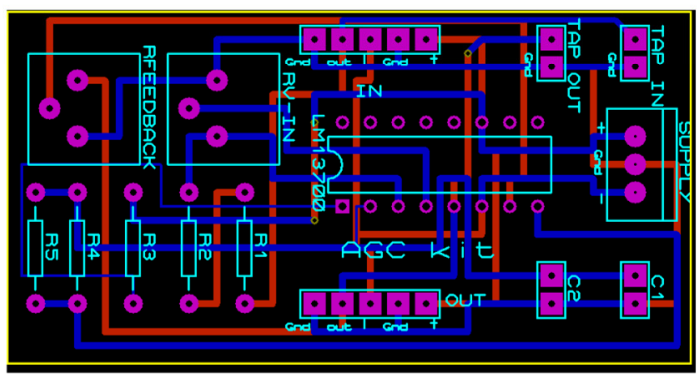

(j)

Figure 5. PCB layout of educational kits for VLC consisting transimpedance amplifier kit: (a) significant size wrapped; (b) small size packaged viewed on the bottom layer; (c) small size packaged viewed on the top layer, (d) Summing Amplifier kit; the Noninverting Amplifier kit: (e) for Op. Amp with one channel; (f) for Op. Amp with two channels; Inverting Amplifier kit: (g) for Op. Amp with one channel; (h) for Op. Amp with two channels; (i) Analog Filter kit; (j) AGC kit 


\section{Macrothink}

The primary circuits for designing the VLC system are shown in Figure 4. It contains: (1) a transimpedance amplifier circuit with photoconductive mode (Figure 4a); (b) Negative noninverting summing amplifier (Figure 4b); (c) some researchers use a differential amplifier circuit to represent the function as a DC-offset remover; (d) Noninverting (Figure 4c) or Inverting configurations (Figure 4d) to describe the role as voltage amplifier; (e) analog filter with second order HPF (Sallen-key topology) as depicted in Figure 4d, some researchers use the LPF, BPF, or BSF depending on the filtered frequency specification, (f) and additional parts in the analog section of VLC system, e.g. AGC.

All of the above circuits realized into double layer PCB that refer to Figure 3 that was developed by using PROTEUS 7.0 as depicted in Figure 5 (Please see in the Appendix section). Afterward, we generate the PCB layout into 3D view in ARESC as shown in Figure 6 . These circuits are then printed-out and mounting its electronic components.

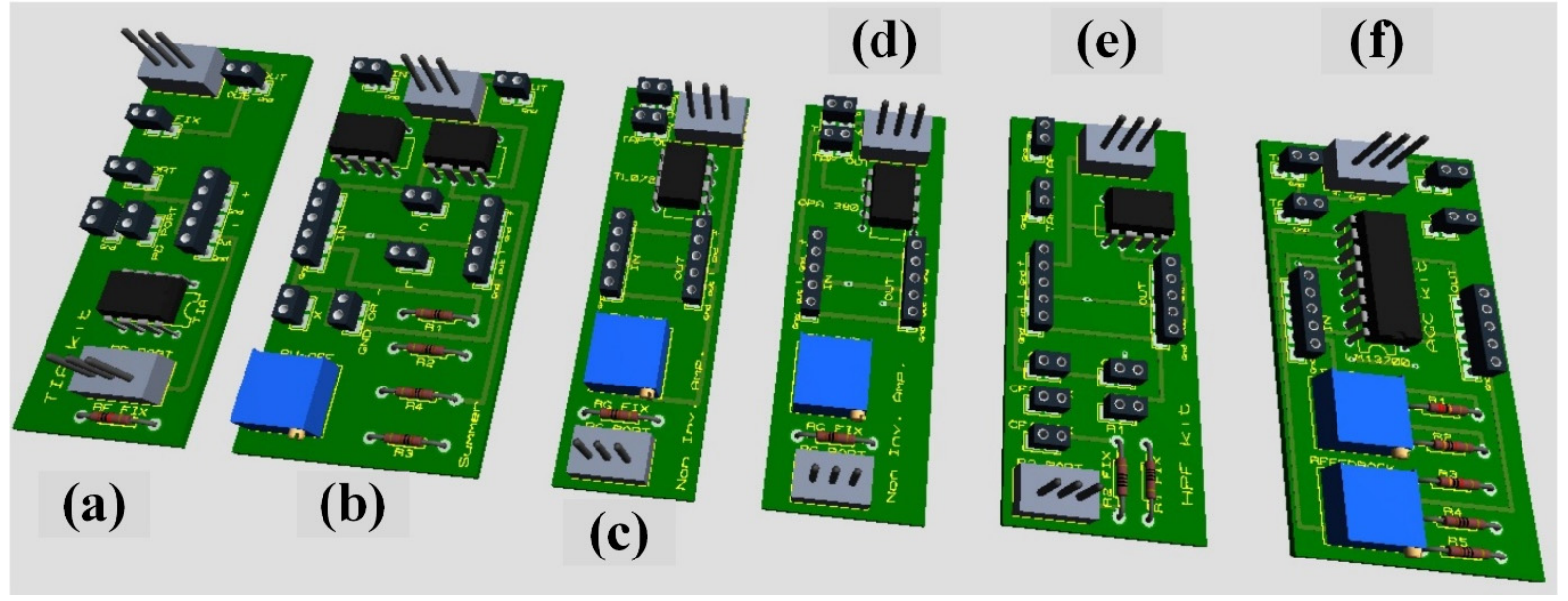

Figure 6. PCB of educational kits for VLC

\section{Results and Discussions}

Figure 7 shows the implementation kits from Figure 6. Several experiments were developed and implemented using the educational VLC kits, these experiments described in Table 1. This lab sequence used for undergraduate student level. We arranged in a bottom-up course based. The coverage includes: (0) Introduction; (1) converting light to voltage using transimpedance amplifier; (2) Gain investigation and its bandwidth measurement using inverting and noninverting amplifier; (3) experiment for compensating the DC signal in receiver front-end; (4) interference filtering using HPF; (5) trial for auto-gain employing IC LM13700; (6) real-time audio transmission wireless system, without the use DSP, utilizing all educational VLC kits as final exam; and (7) final/last project. 


\section{MInstitute ${ }^{\text {Mink }}$}

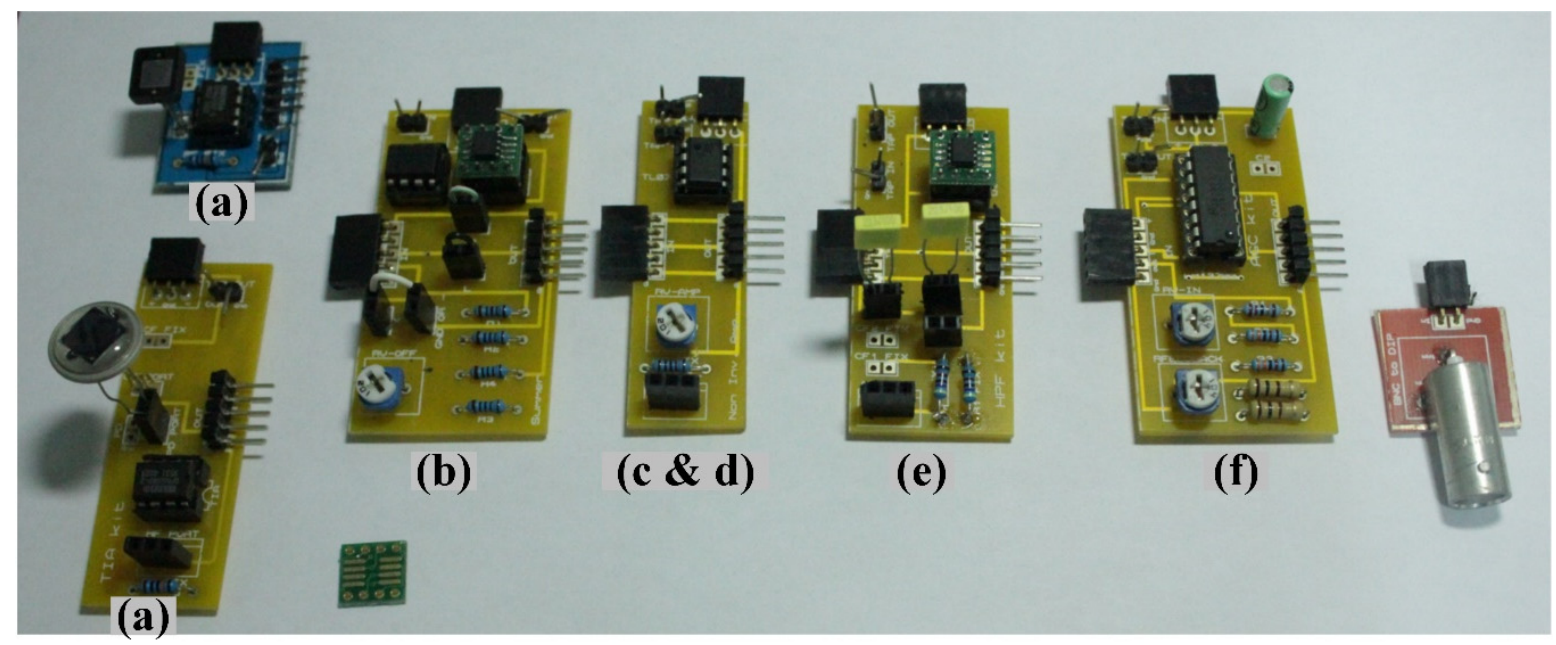

Figure 7. A photograph VLC educational kits

Table 1. Several experiments offered to practice the proposed VLC educational kits

\begin{tabular}{|c|c|c|}
\hline Activities & Kit to be used & Description \\
\hline $\begin{array}{l}3 \text { Hours } \\
\text { expected }\end{array}$ & None & $\begin{array}{l}\text { This activity explains the operation of the essential electronic } \\
\text { components for low-complexity VLC system, such as Op Amp, } \\
\text { photodiode, LED, and the transistor (both bipolar and field } \\
\text { effect), and how to use them in practical yet straightforward } \\
\text { circuits. The undergraduate students also learn to design more } \\
\text { complex courses, such as how to analyze circuits employing Op } \\
\text { Amp configuration. } \\
\text { Then learn how the VLC works and building the blocks. Later, } \\
\text { the lecturer gives the introduction how to use the educational } \\
\text { kits in each task. Identify and use measurement tools in the } \\
\text { experiment that is a digital oscilloscope, signal generator, and a } \\
\text { frequency analyzer. The last is the software used in which for } \\
\text { this work we used TINA }\end{array}$ \\
\hline $\begin{array}{l}6 \text { Hours } \\
\text { expected }\end{array}$ & $\begin{array}{l}\text { Transimpedance } \\
\text { Amplifier } \\
\text { (Figure 4a) }\end{array}$ & $\begin{array}{l}\text { There are several types of signal amplification circuits on the } \\
\text { first stage of VLC system. One of them is The transimpedance } \\
\text { amplifier that is simple to implement. It provides } \\
\text { current-to-voltage (I-V) conversion by using shunt } \mathrm{R}_{\mathrm{f}} \text { around an } \\
\text { inverting amplifier (S. Fuada et al., 2016: } 31-35 \text { ). } \\
\text { In this experiment, the students were required to prepare tools } \\
\text { and materials. i.e., digital oscilloscope, signal generator, } \\
\text { different Op Amps at least five types (e.g., OPA380, OPA620, } \\
\text { TL072, AD8011AN, LM358, etc.). Then different low-cost } \\
\text { photodiodes at least three types (e.g., SP-8ML, BPX65, } \\
\text { S1227-66BK, etc.). The last one is LED driver to transmit } \\
\text { sinusoid signal with linear topology (S. Fuada et al., 2016: } \\
\text { 371-375) or square signal with switch topology of the LED }\end{array}$ \\
\hline
\end{tabular}




\begin{tabular}{|c|c|c|}
\hline & & $\begin{array}{l}\text { driver (T. Adiono et al., 2016: 319-327). } \\
\text { The tasks offered is the student must measure the bandwidth of } \\
\text { the transimpedance amplifier by using a combination of } \\
\text { photodiodes and Op Amps, both based on the simulation or real } \\
\text { practice. The answer key for this testing is presented by S. } \\
\text { Fuada (2017) and T. Adiono et al. (2017: 1375-1380). }\end{array}$ \\
\hline $\begin{array}{l}\text { Experiment } \\
\text { II } \\
5 \text { Hours } \\
\text { expected }\end{array}$ & $\begin{array}{l}\text { Noninverting } \\
\text { amplifier (Figure } \\
\text { 4c) and Inverting } \\
\text { amplifier (Figure } \\
\text { 4d) }\end{array}$ & $\begin{array}{l}\text { The next experiment is amplifier circuit test using noninverting } \\
\text { and inverting configuration. To complete the investigation, } \\
\text { students must understand how to calculate the ac gain of the } \\
\text { circuit to obtain the desired performance. }\end{array}$ \\
\hline $\begin{array}{l}\text { Experiment } \\
\text { III } \\
2 \text { Hours } \\
\text { expected }\end{array}$ & $\begin{array}{l}\text { DC-offset remover } \\
\text { (Figure } 4 \mathrm{~b} \text { ) }\end{array}$ & $\begin{array}{l}\text { The optical wireless communication system including VLC is } \\
\text { vulnerable to the ambient light source that generates DC signal } \\
\text { like a flashlight, sunlight, or LED lamp (S. Fuada et al., 2017: } \\
\text { 14-30) (T. Adiono et al., 2016: 581-584). Therefore, it is crucial } \\
\text { to involve appropriate analog circuit to reject unwanted DC noise } \\
\text { because it can make signal distortion (clipped signal) in the VLC } \\
\text { receiver. } \\
\text { The measurement tools used a digital oscilloscope to know the } \\
\text { behavioral of the received signal before and after filtering, while } \\
\text { the components used DC lamp. The answers key for this testing } \\
\text { are presented by T. Adiono (2017: 616-619). }\end{array}$ \\
\hline $\begin{array}{l}\text { Experiment } \\
\text { IV } \\
6 \text { Hours } \\
\text { expected }\end{array}$ & $\begin{array}{l}\text { Analog Filter } \\
\text { (Figure 4f) }\end{array}$ & $\begin{array}{l}\text { The VLC system also suffers from the other illuminations like } \\
\text { fluorescent and incandescent because it can generate } 100 \mathrm{~Hz} \text { to } \\
150 \mathrm{~Hz} \text { of the carrier frequency (T. Adiono et al., 612-615) so it is } \\
\text { also essential to employ an appropriate analog filter to reject } \\
\text { unwanted noise in the recovered data signal. Frequency analyzer } \\
\text { is used to analyze the SNR of the noise signal. }\end{array}$ \\
\hline $\begin{array}{l}\text { Experiment } \\
\text { V } \\
3 \text { Hours } \\
\text { expected }\end{array}$ & $\begin{array}{l}\text { AGC } \\
\text { (Figure 4f) }\end{array}$ & $\begin{array}{l}\text { In this experiment, the students test the AGC circuit using IC } \\
\text { LM13700 to maintain the voltage gain against the changing of } \\
\text { the input amplitude as well as input frequency. The answer key } \\
\text { for this testing is presented by S. Fuada (2017). }\end{array}$ \\
\hline $\begin{array}{l}\text { Experiment } \\
\text { VI }\end{array}$ & educational & $\begin{array}{l}\text { In the last experiment, students build all circuits to consolidate } \\
\text { the theoretical knowledge acquired in lectures and to learn the } \\
\text { practical aspects. The audio signal generated by MP3 or } \\
\text { audio-out of personal computer/laptop is chosen as an input } \\
\text { signal, while the output of AGC circuit connects to the load ( } 8 \\
\text { Ohm loudspeaker). The methods of real-time transmission are by } \\
\text { playing the music and immediately heard on the speaker. Figure } \\
\text { 8(a) shows the setting of this experiment. }\end{array}$ \\
\hline Projects & $\begin{array}{l}\text { All educational } \\
\text { kits }\end{array}$ & $\begin{array}{l}\text { Advanced students ready for an inductive approach to use this kits } \\
\text { in their projects such as Li-Fi application as shown in Figure } 8 \text { (b) }\end{array}$ \\
\hline
\end{tabular}




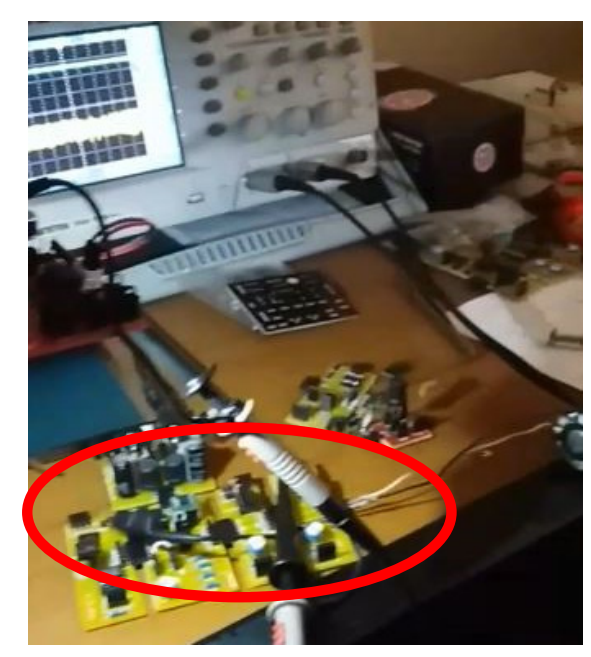

(a)

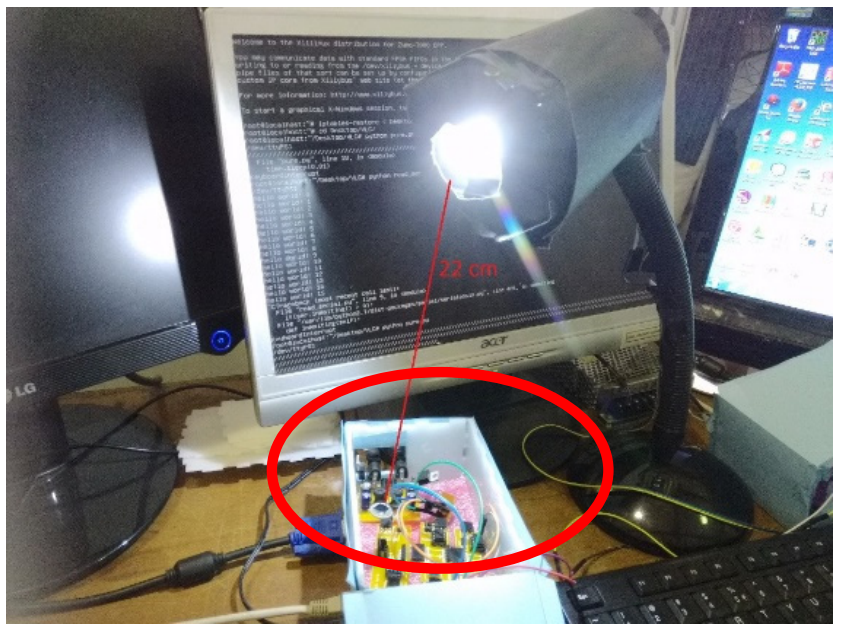

(b)

Figure 8. (a) Audio transmission system (S. Fuada \& T. Adiono, 2017: 352-360), (S. Fuada et al., 2017: 398-403); (b) educational kits for the Li-Fi application (T. Adiono et al., 2017), (T. Adiono et al., Unpublished)

\section{Conclusion and Future Work}

We have proposed each kit to build VLC system for undergraduate student practicum. These educational kits present a low-cost alternative for educators to give a lecture the physical layer of a low-speed VLC application. We also provide the tasks for a reference experiment in which the students may build on. For future works, we will provide the DSP board such as general microcontroller or FPGA so the BER analysis of the experiment can be involved. Moreover, it is essential to include the eye diagram within the practicum for VLC system.

\section{Acknowledgment}

This research is one part of the big project entitled "Machine-to-machine Communication (M2M) based on Visible Light Communication (VLC)". The Ministry of Research, Technology and Higher Education of the Republic Indonesia funded it through Kerjasama Luar Negeri (KLN) scheme with Pukyong National University (PKNU), Republic of South Korea (Contract No. 009/SP2H/LT/DRPM/IV/2017).

\section{References}

Adiono, T., \& Fuada, S. (2017). Investigation of Optical Interference Noise Characteristics in Visible Light Communication System. Proc. of the 2017 Int. Symp. on Nonlinear Theory and Its Applications (NOLTA), 612-615.

Adiono, T., \& Fuada, S. (2017). Optical Interference Noise Filtering over Visible Light Communication System Utilizing Analog High-Pass Filter Circuit. Proc. of the 2017 Int. Symp. on Nonlinear Theory and Its Applications (NOLTA), 616-619. 
Adiono, T., Fuada, S., \& Harimurti, S. (2017). Bandwidth Budget Analysis for Visible Light Communication Systems utilizing Commercially Available Components. Proc. of the $10^{\text {th }}$ Int. Conf. on Electrical and Electronics Engineering (ELECO), 1375-1380.

Adiono, T., Fuada, S., Putra, A.P., \& Aska, Y. (2016). Desain Awal Analog Front-End Optical Transceiver untuk aplikasi Visible Light Communication. J. Nasional Teknik Elektro dan Teknologi Informasi (JNTETI), 5(4), 319-327. https://doi.org/10.22146/jnteti.v5i4.280

Adiono, T., Fuada, S., Saputro, R. A., \& Luthfi, M. (n.d.). Internet Access over Visible Light. Unpublished.

Adiono, T., Pradana, A., Putra, R. V. W., \& Fuada, S. (2016). Analog Filters Design in VLC Analog Front-End Receiver for Reducing Indoor Ambient Light Noise. Proc. of the IEEE Asia Pacific Conf. on Circuit and Systems (APCCAS), 581-584. https://doi.org/10.1109/APCCAS.2016.7804058.

Adiono. T., Fuada, S., Luthfi, M., \& Saputro, R.A. (2017). MAC Layer Design for Network-Enabled Visible Light Communication Systems Compliant with IEEE 802.15.7. EAI Endorsed Transactions on Energy Web and Information Technology, 4(14). https://doi.org/10.4108/eai.4-10-2017.153163.

Akram, A.A., Khader, S. \& Hasan, O. (2011). Implementation of Dual Use Fiber Optic Communications Laboratories. iJOE, 7(2), 4-9. https://doi.org/10.3991/ijoe.v7i2.1637

Akram, A-A. \& Hill, J. (2008). Fiber Optic Communications Educational Toolkit. ASEE National Conf.. $\quad$ Retrieved from http://www.nebhe.org/wp-content/uploads/Fiber_Optics_Toolkit.pdf

Figueiredo, M., Alves, L.N., \& Ribeiro, C. (2017). Lighting the wireless world: The promise and challenges of visible light communication. IEEE Consum. Electron. Mag., 6(4), $28-37$.

Fuada, S. \& Adiono, T. (2017). Rancang Bangun Layer Fisik Visible Light Communication Pada Sistem Transmisi Audio. J. INFOTEL, 9(3), 352-360. https://doi.org/https://doi.org/10.20895/infotel.v9i3.288.

Fuada, S. (2017). Design and Implementation of Analog Front-End Transceiver Module for Visible Light Communication System. M.T. thesis, Dept. Elect. Eng., School of Electrical Engineering and Informatics, Institut Teknologi Bandung, Bandung, Indonesia.

Fuada, S., Adiono, T., Putra, A.P. \& Aska, Y. (2016). A Low-cost Analog Front-End (AFE) Transmitter Designs for OFDM Visible Light Communications. Proc. of the IEEE Int. Symposium on Electronics and Smart Devices (ISESD), 371-375. https://doi.org/10.1109/ISESD.2016.7886750

Fuada, S., Putra, A.P., \& Adiono, T. (2017). Short-range Audio Transfer through 3 Watt White LED based on LOS Channels. Proc. of Int. Conf. on Intelligent Signal Processing and Communication Systems (ISPACS), 398-403. https://doi.org/10.1109/ISPACS.2017.8266511.

Fuada, S., Putra, A.P., Aska, Y. \& Adiono, T. (2017). A First Approach to Design Mobility Function and Noise Filter in VLC System Utilizing Low-cost Analog Circuits. Int. J. of 
Recent Contributions from Engineering, Science, and IT (iJES), 5(2), 14-30. https://doi.org/10.3991/ijes.v5i2.6700.

Fuada, S., Putra, A.P., Aska, Y., \& Adiono, T. (2016). Trans-impedance Amplifier (TIA) Design for Visible Light Communication (VLC) using Commercially Available OP-AMP. Proc. of the $3^{\text {rd }}$ Int. Conf. on Information Tech. Computer, and Electrical Engineering (ICITACEE), 31-35. https://doi.org/10.1109/ICITACEE.2016.7892405

Fuada, S., Saputro, R.A., \& Adiono, T. (2017). Automatic Gain Control Circuit for Mobility Visible Light Communication System using LM13700. Proc. of the IEEE Int. Symposium on Electronics and Smart Devices (ISESD).

Johnson, A.M et al. (2007). Hands-on optics: an informal science education initiative. Novel Optical Systems Design and Optimization, 6668. https://doi.org/10.1117/12.740568

Lee, C.G. (2011). Visible Light Communication. Intechopen Advanced Trends in Wireless Communications, 328-338.

Oliveira, L.B. et al. (2017). Undergraduate Electronics Projects Based on the Design of an Optical Wireless Audio Transmission System. IEEE Transactions on Edu., 60(2), 105-111.

Vasinek, V. et al. (2009). From university to company - education of optical communications in cooperation with industry at Technical University of Ostrava, Education and Training in Optics and Photonics. https://doi.org/10.1364/ETOP.2009.EMCB2

Wang, Q., Giustiniano, D., \& Gnawali, O. (2015). Low-Cost, Flexible and Open Platform for Visible Light Communication Networks. Proc. of the $2^{\text {nd }} A C M$ Workshop on Hot Topics in Wireless.

Windlin, C. \& Laaksolahti, J. (2017). Unpacking Visible Light Communication as a Meterial for Design. Proc. of the 2017 CHI Conf. on Human Factors in Computing Systems, 2019-2023.

Windlin, C. (2017). Visible Light Communication as a Meterial for Design. KTH Royal Institute Technology, School of Computer Science and Communication.

Zamora, J. (2017). Demo: An Open-Access Research Testbed for Visible Light Communication. Proc. of VLCS, 31.

\section{Copyright Disclaimer}

Copyright reserved by the author(s).

This article is an open-access article distributed under the terms and conditions of the Creative Commons Attribution license (http://creativecommons.org/licenses/by/3.0/). 